\title{
Management Of A Governmental Organization
}

\author{
Mohammad Reza Lori Pari Zanganeh \\ Office Expertise Technician, Atrak Paper Factory \\ Niloufra Zanganehnia \\ Office Expertise \\ niloubano1367@gmail.com
}

\begin{abstract}
In The Connecting Ages, nowadays Active Is An a Organizational Key Property Having Extra Importance In The Complicated Organizational Environment . Subbject Of This Research Is active Pattern Of Governmental Organizational In Iran ,The Case Study ,Petro Administration In IRI.Main Matter Of The Research, The Applierd Suggestion Through The Research After Designing The Mode Is That Establishing An Optimum Pattern In Governmental Organization Is Related To An Excellent Mangment Of Responsible Educating Person And Making Cultural Affairs Are Important With Regards to activity .In Petro Administration.so Weak Aspects In this Organization Will Be Removed.
\end{abstract}

Key words: Activity ,Governmental Organization

\section{Introduction}

An intergovernmental organization or international governmental organization (IGO) is an organization composed primarily of sovereign states (referred to as member states), or of other intergovernmental organizations. Intergovernmental organizations are often called international organizations, although that term may also include international nongovernmental organization such as international nonprofit organizations or multinational corporations. Intergovernmental organizations are an important aspect of public international law. IGOs are established by treaty that acts as a charter creating the group. Treaties are formed when lawful representatives (governments) of several states go through a ratification process, providing the IGO with an international legal personality. Nongovernmental organizations, nongovernmental organizations, or nongovernment organizations, commonly referred to as NGOs, are international organizations and generally nonprofit organizations independent of specific governments (though often funded by governments) that are active in humanitarian, educational, healthcare, public policy, social, human rights, environmental, and other areas to effect changes according to their objectives. Early examples of organizations that would now be termed a government agency include the British Navy Board, responsible for ships and supplies, which was established $^{[1]}$ in 1546 by King Henry VIII and the British Commissioners of Bankruptcyestablished $^{[2]}$ in 1570.

From 1933, the New Deal saw rapid growth in US federal agencies, the "alphabet agencies" as they were used to deliver new programs mandated by legislation, such as federal emergency relief.

From the 1980s, as part of New Public Management, several countries including Australia and the United Kingdom developed the use of agencies to improve efficiency in public services.

Satisfied, highly-motivated and loyal employees represent the basis of competitive company. The growth of satisfaction is to be reflected in the increase of productivity, improvement of the products' quality or rendered services and higher number of innovations. Satisfied employees form positive reference to the employer and thus increase its 
attractiveness for potential job seekers and strengthen its competitive position in the market. Management of the company does not often know opinions of own employees and underestimates dependence between satisfaction of employees and total successfulness of the company in the market. The article brings the results of the employees' survey in the field of human resources management in the financial sector, factors of the satisfactions which can significantly influence the motivation of the employees and identify problem areas in the human resources management in the organization of the financial sector. The survey affirms that the orientation of the personal policy, i.e. management of the career, working conditions, and environment is a problem area in the human resources management in the researched organization. Based upon experience implementation of personal policy should be done step by step and successful achievement can last a few years. Before implementation management should clearly define why we are here, what is our aim and how we intend to attain defined target. Simultaneously executives should not underestimate employees' opinion on one hand and take into consideration current external environment which can influence human resources management on the other hand.

A clear set of goals and objectives is fundamental to the success of a department. Specifically, a department or work unit should have (1) a mission statement, (2) written goals and objectives for the department as a whole, and (3) written goals and objectives for each significant activity in the department (see diagram below). Furthermore, goals and objectives should be expressed in terms that allow meaningful performance measurements.

Department Activities to Activity Level Mission Goals and Achieve Goals and Objectives and Objectives There are certain activities which are significant to all departments: budgeting, purchasing goods and services, hiring employees, evaluating employees, accounting for vacation/sick leave, and safeguarding property and equipment. Thus, all departments should have appropriate goals and objectives, policies and procedures, and internal controls for these activities.

\section{. Control Activities - Reviews}

- Budget to actual comparison

- Current to prior period comparison

- Performance indicators

- Follow-up on unexpected results or unusual items

Reviewing reports, statements, reconciliations, and other information by management is an important control activity; management should review such information for consistency and reasonableness. Reviews of performance provide a basis for detecting problems. Management should compare information about current performance to budgets, forecasts, prior periods or other benchmarks to measure the extent to which goals and objectives are being achieved and to identify unexpected results or unusual conditions which require follow-up. Management's review of reports, statements, reconciliations, and other information should be documented as well as the resolution of items noted for follow-up.

\section{Control Activities - Asset Security}

- Security of physical and intellectual assets

- Physical safeguards

- Perpetual records are maintained

- Periodic counts/physical inventories

- Compare counts to perpetual records

- Investigate/correct differences 
Liquid assets, assets with alternative uses, dangerous assets, vital documents, critical systems, and confidential information must be safeguarded against unauthorized acquisition, use, or disposition. Typically, access controls are the best way to safeguard these assets. Examples of access controls are as follows: locked door, key pad systems, card key system, badge system, locked filing cabinet, guard, terminal lock, computer password, menu protection, automatic callback for remote access, smart card, and data encryption. Departments with capital assets or significant inventories should establish perpetual inventory control over these items by recording purchases and issuances. Periodically, the items should be physically counted by a person who is independent of the purchase, authorization and asset custody functions, and the counts should be compared to balances per the perpetual records. Missing items should be investigated, resolved, and analyzed for possible control deficiencies; perpetual records should be adjusted to physical counts if missing items are not located.

\section{Create employee personal development plans}

Employees nowadays want to know, "What's in it for me?" Tell them! A personal development plan shows the employee the areas of improvement he will focus on during the next six to 12 months, incorporates both his long-term and short-term goals, details the experience, skills and proficiencies he must demonstrate to be promoted, and shows the role his position plays in, and the affect it has on, the company.

\section{Encourage employees to share their thoughts and ideas.}

Most employees are dedicated, have integrity and want to contribute. Allow them to do this by actively encouraging your people to share their thoughts and ideas. Providing an open forum for them to be heard can be invaluable toward building trusting relationships.

Recognition. Recognize outstanding performance publicly. This rewards the individual employee while demonstrating to your other people that you care about them and are in their corner.

\section{Conclusion}

Based upon the results, it can be stated that defined goal is reached because the results show a complex view on the management of human resources. At the same time, the research presents a detailed answer which factors influence the performance of employees. Simultaneously, it is found out which areas require increased attention by managers of human resources in order to increase the performance of employees and thus the overall performance of the organization. Employees' survey is one of the important tools of the communication means in each company. Opinions of employees regarding the company can support the company for the right development and direction.

\section{References}

1. FOOT, M. - HOOK, C.: Personalistika. Brno. CP Books. 2005, 462 p. ISBN 807226-5156-

2. HALL, B. W.: The New Human Capital Strategy. New York. Amacon. 2008. ISBN 978-05-0927-8144-

3. HERZBERG, F. W. - MAUSNER, B. - SNYDERMAN, B.: The Motivation Work. New York. Wiley, Library of Congress, 92-16067. 1957. ISBN 1-56000-634-X

4. KHAN, K. U. - FAROOQ, S. U. - ULLAH, M. I.: The Relationship between Rewards and Employee Motivation in Commercial Banks of Pakistan. [online] Research Journal of International Studies. 2010. Issue 14

5. KOUBEK, J.: Ř́zení pracovního výkonu. Praha. Management Press. 2004, 210 p. ISBN 80-116-7261-X 
6. PORVAZNÍK, J.: Celostný manažment. Poradca podnikatel'a. 2007. ISBN 978-80889317-73-

7. ŠVECOVÁ, S.: Personálny manažment. Bratislava. Dr. Josef Raabe Slovensko. Október 2009

8. Shannon, Megan. "The Expansion of International Organizations" Paper presented at the annual meeting of the American Political Science Association, Hilton Chicago and the Palmer House Hilton, Chicago, IL, Sep 02, 2004 <Not Available>. 2009-05-26

9. "Non-Governmental Organizations (NGOs) in the United States" (fact sheet). January 20, 2017. Bureau of Democracy, Human Rights, and Labor. U.S. Department of State. state.gov. Retrieved 2017-09-21. 